\title{
Perkembangan Bahasa Anak: Analisis Komunikasi Siswa
}

\author{
Rohaina $^{1}$ \\ ${ }^{1}$ SDN 86/X Harapan Makmur, Jambi, Indonesia
}

\begin{tabular}{l}
\hline \hline Article Info \\
\hline Article history: \\
Received Mei 12, 2020 \\
Revised Mei 19, 2020 \\
Accepted Mei 28, 2020
\end{tabular}

\section{Keywords:}

Bahasa Anak

Komunikasi

Siswa

\begin{abstract}
ABSTRAK
Tujuan Penelitian: Tujuan penulisan artikel ini adalah untuk meningkatkan kemampuan anak dalam bahasa.

Metodologi: Penelitian menggunakan jenis kualitatif dengan subjek yang digunakan adalah siswa Sekolah Dasar 86, Instrumen pada penelitian ini menggunakan observasi dan analisis menggunakan miles \& huberman.

Temuan Utama: Bahasa merupakan alat komunikasi untuk menyampaikan pesan, yang dapat digunakan untuk berfikir dan mengungkapkan perasaan sehingga bahasa dapat menerima pikiran dan perasaan orang lain. Perkembangan bahasa dimulai sejak bayi dan mengandalkan perannya pada pengalaman, penguasaan dan pertumbuhan bahasa pada anak. Sehingga perkembangan bahasa pada anak memiliki beberapa faktor yang mendukung baiknya bahasa anak seperti umur anak, kecerdasan, lingkungan, status sosial, dan keadaan fisik.
\end{abstract}

Aplikasi dalam Penelitian: Pengembangan media pembelajaran sangat penting dilakukan agar terciptanya pembelajaran yang menarik siswa.

Keterbarauan: Keterbaruan dalam penelitian ini adalah produk untuk media pembelajaran matematika untuk siswa sekolah dasar.

Copyright (C) 2020 Cahaya Ilmu Cendekia Publisher. All rights reserved.

\section{Corresponding Author:}

Komariah

SDN 98/X Rantau Indah, Jambi, Indonesia

Email: komariah@gmail.co.id

\section{PENDAHULUAN}

Dalam hidup bermasyarakat, seseorang perlu berkomunikasi agar dapat respon positif dari orang lain dalam kehidupan sehari-hari. Terdapat dua cara dalam berkomunikasi, baik secara lisan maupun tertulis. Penggunaan bahasa secara lisan merupakan tuturan langsung, sedangkan bahasa secara tertulis merupakan tuturan tersirat melalui tulisan (tidak langsung).

Salah satu tujuan seseorang dalm berbicara kepada lawan bicara adalah untuk mengutarakan pesan yang ingin di sampaikan. Dalam menyampaian pesan, biasanya menggunakan bahasa yang mudah dipahami kedua belah pihak. Tujuan komunikasi dalam hubungan antar makhluk sosial dilakukan dengan menggunakan beberapa strategi, misalnya dengan memakai ungkapan yang bersifat sopanan, ungkapan yang baik dan basa-basi. [1, 2]. Bahasa sangat penting bagi manusia, karena manusia merupakan makhluk sosial yang berinteraksi dengan lingkungannya. Bahasa terus berkembang, mulai dari satu kata, satu kalimat, dan seterusnya. Untuk itu perlu penelusuran dalam perkembangan bahasa yang dialami oleh peserta didik. Perkembangan bahasa tersebut selalu meningkat sesuai dengan meningkatnya usia anak. Perkembangan bahasa pada anak sangat penting karena anak dapat mengembangkan kemampuan sosialnya (social skill) melalui berbahasa [3].

Bahasa Indonesia berfungsi sebagai bahasa pengantar di semuajenis pendidikan danjenjang sekolah, mulai dari TK sampai PerguruanTinggi di Indonesia. OIeh karena fungsi tersebut, maka bahasa memegang peranan penting daIampembaharuan dan peningkatan mutu pendidikan. Khususnya di TK, fungsi bahasa ini 
dijelaskan dalam Depdikbud (1996) bahwa: pengembangan kemampuan berbahasa di TK bertujuan agar anak didik mampu berkomunikasisecara lisan dengan lingkungannya [4]. Selanjutnya, dinyatakan lingkungan yang dimaksud adalah lingkungan di sekitar anak antara lain lingkungan ternan sebaya, ternan bermain, orang dewasa, baik yang ada di rumah, di sekolah, maupun dengan tetangga di sekitartempat tinggalnya. Oleh karena itu, pemahaman tentang perkembangan bahasa anak tidakboleh diabaikan begitu saja oleh guru. Oimilikinyawawasan guru tentang perkembangan bahasa tersebut, diharapkan menjadi dasar dan ramburambu pada saat guru melaksanakan program pembelajarannya.

Bahasa mencakup setiap bentuk komunikasi yang ditimbulkan oleh pikiran dan perasaan untuk menyampaikan makna kepada orang lain [5]. Dalam bahasa tersebut, diperlukan penggunaan tanda-tanda atau simbul ke dalam sebuah tatabahasa yang berada dalam struktur aturan tertentu. Anak akan mengerti ungkapan seseorang karena melalui perbendaharaan kata yang disampaikan. Akan tetapi, apabila tidak dimiliki sejumlah perbendaraan kataatau kosa kata, yang akan digunan sebagai elemen berbicara, anak tidak dapat berbicara atau berkata-kata. Dengan demikian, meskipun sarana lain untuk berbicara terpenuhi, jika tidak memiliki kosakata, seseorang/anak tidak dapat berbicara [6]. Jadi, bahasa tidak sama dengan bicara.

Maka dari itu, tujuan dalam penelitian ini adalah untuk meningkatkan kemampuan anak dalam bahasa.

\section{METODE PENELITIAN}

Penelitian deskriptif kualitatif merupakan penelitian yang termasuk dalam jenis penelitian kualitatif. Tujuan dari penelitian ini adalah mengungkapkan fakta, keadaan, fenomena, variabel dan keadaan yang terjadi saat penelitian berjalan dan menyuguhkan apa adanya. Penelitian deskripsi kualitatif menafsirkan dan menuturkan data yang bersangkutan dengan situasi yang sedang terjadi, sikap serta pandangan yang terjadi di dalam masyarakat, pertentangan 2 keadaan atau lebih, hubungan antar variabel, perbedaan anatar fakta, pengaruh terhadap suatu kondisi, dan lain-lain masalah yang diteliti dan diselidiki oleh penelitian deskriptif kualitatif mengacu pada studi kuantitatif, studi komparatif, serta dapat juga menjadi sebuah studi korealisional 1 unsur bersama unsur lainnya. Biasanya kegiatan penelitian ini meliputi pengumpulan data, menganalisis data, menginterprestasi data dan diakhiri dengan sebuah kesimpulan yang mengacu pada penganalisisan data tersebut.

Subjek penelitian ini adalah siswa SD Negeri 86/X Harapan Makmur, sedangkan objek penelitiannya adalah analisis perkembangan bahasa anak dalam berkomunikasi di sekolah. Prosedur penelitian yang dilakukan oleh peneliti dalam pelaksanaan penelitian ini, agar dapat diperoleh bagaimana perkembangan bahasa anak dalam berkomunikasi di SD Negeri 86/X Harapan Makmur. Peneliti menyusun instrumen penelitian berdasarkan tujuan penelitian dan jenis data yag dijadikan sumber penelitian. Peneliti juga melakukan observasi dengan tujuan untuk mendapatkan informasi yang diperlukan. Observasi adalah suatu proses pengamatan yang secara terstruktur tentang suatu fenomena yang diteliti. Observasi merupakah salah satu teknik pengumpulan data, yang sesuai dengan tujuan penelitian yang dirancang dan ditulis secara terstruktur sehingga dapat ditinjau dengan keunggulan dan kebenarannya. Arikunto menjelaskan bahwa "Observasi merupakan suatu aktivitas atau kegiatan yang dilakukan seseorang terhadap suatu objek untuk mendapatkan informasi yang dibutuhkan dengan memahami pengetahuan dari suatu fenomena berdasarkan pengetahuan yang telah diketahui sebelumnya [7].

\section{HASIL DAN PEMBAHASAN}

Hasil penelitian yang telah dilakukan dapat dilihat pada tabel berikut:

Tabel 1. Hasil observasi

\begin{tabular}{ll}
\hline \multicolumn{1}{c}{ Indikator Kemampuan Bahasa Anak } & \multicolumn{1}{c}{ Deskripsi } \\
\hline Menyimak Perkataan Orang Lain & $\begin{array}{l}\text { Anak menyimak Perkataan dari orang lain namun belum } \\
\text { begitu fokus dikarenakan adanya faktor Lain seperti anak }\end{array}$ \\
$\begin{array}{l}\text { ingin bermain dan acuh tak acuh } \\
\text { Mengungkapkan perasaan dengan kata } \\
\text { sifat (baik, senang, nakal, pelit, jelek, dan sudah bisa mengungkapkan pendapat dengan baik } \\
\text { sebagainya) }\end{array}$ & $\begin{array}{l}\text { dalam menggunakan kata sifat namun masih memiliki } \\
\text { kendala dalam mengungkapkan perasaan yang ingin } \\
\text { dibicarakannya. }\end{array}$ \\
Mengutarakan pendapat kepada orang lain & $\begin{array}{l}\text { Dalam mengutarakan pendapat anak masih terkendala } \\
\text { dalam penggunakan bahasa atau Kosakata yang tepat. }\end{array}$ \\
Menyatakan alasan terhadap sesuatu yang & $\begin{array}{l}\text { Anak belum bisa memberikan alasan dengan } \\
\text { menggunakan kosakata yang baik dan benar. }\end{array}$ \\
\hline
\end{tabular}


Setelah selesai melakukan observasi, peneliti melihat masih banyak anak yang berkomunikasi menggunakan kosakata yang tidak baku misalnya, anak dalam berbicara masih menggunakan bahasa daerah setempat. Sehingga dalam berkomunkasi anak menggunakan bahasa daerah bukan menggunakan bahasa Indonesia. Banyaknya kendala atau faktor yang menghambat dalam perkembangan bahasa anak.

\section{Konsep bahasa}

Bahasa merupakan alat komunikasi berupa lambang bunyi yang di hasilkan dari alat ucap yang digunakan manusia untuk menghasilkan gagasan sehingga orang yang menerima akan memahami gagasan yang disampaikan, baik penyampaian berupa lisan, tulisan, isyarat, ataupun gerakan yang bermakna [8]. Berdasarkan cirinya bahasa dapat diartikan dalam dua cara yang pertama bahasa bercirikan sebagai serangkaian guna. Dalam hal ini bunyi digunakan sebagai alat untuk berkomunikasi, walaupun sebenarnya juga bisa menggunakan alat lain akan tetapi pada umumnya manusia menggunakan bunyi sebagai alat komunikasi yang paling utama. Komunikasi yang menggunakan bunyi disebut dengan komunikasi verbal, sehingga masyarakat yang menggunakan alat komunikasi bunyi dapat dikatakan pula sebagai masyarakat verbal. Yang kedua, bahasa adalah lambang rangkaian bunyi yang membentuk suatu arti, yang dikenal sebagai kata yang melambangkan suatu objek tertentu. Dengan bahasa, manusia dapat berfikir secara sistematis dan dapat menyampaikan apa yang sedang dipikirkannya kepada orang lain.

\section{Klasifikasi Bahasa Anak Usia SD}

Bahasa memiliki cakupan yang luas, karena itu sebagaimana dikemukakan Lerner "Bahasa merupakan alat komunikasi terpadu yang mencakup bahasa ujaran, membaca, dan menulis. Saat pertama kali anak mengetahui keadaan sekitar tentang suatu kejadian dikehidupannya maupun tentang gejala-gejala dan benda-benda yang membantu terjadinya peristiwa, maka saat itu pula pengetahuan anak tentang apa yang dikenalnya belum tumbuh [9]. Secara umum klasifikasi bahasa pada anak usia sekolah dasar dapat dibedakan menjadi bahasa lisan dan bahasa tulis.

\section{Bahasa Lisan}

Bahasa lisan memperlihatkan hubungan secara langsung, karena orang yang bicara secara langsung akan langsung berhadapan satu sama lain. Misalnya: ketika bayi lapar, kedinginan, sakit dan lain-lain. Sebelum anak mengucapkan kata-kata, menangis merupakan cara untuk mengkomunikasikan kepada orang sekitarnya tentang apa yang diinginkannya.

\section{Bahasa Tulis}

Bahasa tulis memperlihatkan hubungan yang tidak langsung karena menggunakan sarana berupa huruf-huruf. Hubungan dalam bahasa tulisan terjadi melalui proses sebagai berikut: pikiran penulis, kata dan kalimat. Tulisan merupakan media yang bisa membuat manusia mengungkapkan rahasia keadaan masa lalu.

\section{Faktor Yang Mempengaruhi Perkembangan Bahasa Anak Usia SD}

Lima faktor yang mempengaruhi perkembangan bahasa pada anak [10], yaitu sebagai berikut:

1. Umur anak, faktor fisik juga ikut mempengaruhi sehubungan semakin sempurnanya pertumbuhan organ bicara, kerja otak otot untuk melakukan gerakan-gerakan dan isyarat.

2. Kondisi lingkungan tempat tumbuh dan berkembangnya anak juga memberi pengaruh yang besar terhadap perkembangan bahasa anak. Perkembangan bahasa di lingkungan pedesaan berbeda dengan lingkungan perkotaan.

3. Kecerdasan anak, diperlukan kemampuan motorik yang baik untuk meniru lingkungan tentang bunyi atau suara, gerakan, dan mengenal tanda-tanda,. Kemampuan motorik seseorang berkorelasi positif dengan kemampuan intelektual atau tingkat berfikir.

4. Status sosial ekonomi keluarga, keluarga yang status sosial ekonominya baik, akan mampu menyediakan situasi yang baik untuk perkembangan bahasa anak dan anggota keluarganya.

5. Keadaan fisik, yaitu keadaan kesehatan anak. perkembangan berbahasa akan terganggu jika orang tersebut mengalami cacat yang dapat mengganggu kemampuannya dalam berkomunikasi seperti bisu, gagap, tuli atau organ suara yang tidak sempurna yang akan mengganggu ketika sedang berkomunikasi.

\section{Perkembangan Bahasa pada Anak Usia SD}

Perkembangan bahasa adalah untuk memehami karakteritik perkembangan bahasa pada anak, bahasa adalah suatu sistem kommunikasi yang digunakan oleh manusia [11]. Kemampuan komunikasi anak usia SD adalah sebagai berikut: 
1. Anak usia 6 tahun

Memiliki kosakata yang dapat dikomunikasikan

Mampu menyerap 20000-24000 kata

Mampu membuat kalimat meskipun masih dalam bentuk kalimat pendek

Pada taraf tertentu sudah mampu mengucapkan kalimat lengkap

2. Anak usia 8 Tahun

Mampu bercakap-cakap dengan menggunakan kosa kata yang dimilikinya

Mampu mengemukakan ide dan pikirannya meskipun masih sering verbalisme.

3. Anak usia 10 tahun

Mampu berbicara dalam waktu yang relatif lama

Mampu memahami pembicaraan

4. Anak Usia 12 tahun

Mampu menyerap 50000 kata

Mampu berbahasa seperti orang dewasa.

Langkah-langkah Dalam Membantu Perkembangan Bahasa pada Anak SD

1. Membaca, merupakan kegiatan yang paling penting yang bisa dilakukan setiap hari bersama anak. ciptakan kegiatan membaca yang menarik dan menyenagkan untuk anak dan lakukan setiap hari.

2. Berbicara menggunakan bahasa yang sederhana tentang kegiatan sederhana yang dilakuakan orang tua dan anak.

3. Memperkenalkan kata-kata baru setiap harinya kepada anak.

4. Cobalah mengapresiasi setiap pembicaraan atau cerita terhadap anak.

\section{KESIMPULAN}

Bahasa merupakan alat komunikasi untuk menyampaikan pesan, yang dapat digunakan untuk berfikir dan mengungkapkan perasaan sehingga bahasa dapat menerima pikiran dan perasaan orang lain. Perkembangan bahasa dimulai sejak bayi dan mengandalkan perannya pada pengalaman, penguasaan dan pertumbuhan bahasa pada anak. Sehingga perkembangan bahasa pada anak memiliki beberapa faktor yang mendukung baiknya bahasa anak seperti umur anak, kecerdasan, lingkungan, status sosial, dan keadaan fisik.

\section{UCAPAN TERIMA KASIH}

Terimakaish kepada seluruh responden yang telah bersedia, sehingga penelitian ini dapat saya selesaikan. Serta semua elemen yang telah ikut berpartisipasi, saya ucapkan terimakasih

\section{REFERENSI}

[1] Kuntarto, Eko, "Modul Matakuliah Bahasa Indonesia Untuk Perguruan Tinggi”. Universitas Jambi.

[2] Alfiana, Rizki dan Eko Kuntarto, "Perkembangan Bahasa Pada Anak Usia Dini". Repository Unja, 2020

[3] Zubaidah, E. "Perkembangan bahasa anak usia dini dan teknik pengembangan di sekolah". Cakrawala Pendidikan, (3), 87931, 2004

[4] Depdikbud. Metodik Khusus Pengembangan Kemamapuan Berbahasa di Taman Kanak-Kanak. Jakarta: Depdikbud 1996.

[5] Hurlock, Elizabeth B. Perkembangan Anak. Judul Asli "child Development" . 1978. diterjemahkan oleh Med. Meitasari Tjandrasa dan Muslikhah Zarkasih.Jakarta: Erlangga, 1998.

[6] Tarmansyah. 1996. Gangguan Komunikasi. Jakarta: Depdikbud. Dirjen Dikti. Proyek PembinaanTenaga Guru

[7] D. A. Kurniawan, A. Astalini, D. Darmaji, R. Melsayanti, "Student's Attitude Towards Natural Science," International Journal of Evaluation and Research in Education (IJERE), vol. 8, no. 3, pp. 463-468, 2019

[8] D. A. Kurniawan, A. Astalini, D. Darmaji, and R. Melsayanti, "Students' attitude towards natural sciences," Int. J. Eval. \& Res. Educ, vol 8, no. 3, pp. 455-460, 2019

[9] D. Darmaji, D.A. Kurniawan and A. Lestari, "Deskripsi Keterampilan Proses Sains Mahasiswa Pendidikan Fisika Pada Praktikum Suhu dan Kalor,” JRKPF UAD, vol. 5, no. 2, pp. 68-72, 2018

[10] A. Asrial, S. Syahrial, D. A. Kurniawan, F. Chan, P. Nugroho, R. A. Pratama, and R. Septiasari, "Identification: The Effect Of Mathematical Competence On Pedagogic Competency Of Prospective Teacher," Humanities \& Social Sciences Reviews (HSSR), vol. 7, no. 4, pp. 85-92, 2019. 